\title{
ECONOMIC AND SOCIAL ASPECTS IN THE ANALYSIS OF PUBLIC POLICIES RELATED TO BRAZILIAN LABOR MARKET AND ITS PERFORMANCE IN THE APPLICATION OF CAPABILITY APPROACH
}

\section{ASPECTOS ECONÓMICOS Y SOCIALES EN EL ANÁLISIS DE LAS POLÍTICAS PÚBLICAS RELACIONADAS AL MERCADO LABORAL BRASILEÑO Y SU DESEMPEÑO EN LA APLICACIÓN DEL ENFOQUE DE LAS CAPACIDADES}

\author{
GUSTAVO BARBY PAVANI* \\ Pontifical Catholic University of the State of Paraná, PUCPR, Brasil \\ MARCO ANTÔNIO CÉSAR VILLATORE** \\ Pontifical Catholic University of the State of Paraná, PUCPR, Brasil \\ Federal University of the State of Santa Catarina, Brasil \\ AUGUSTUS BONNER COCHRAN III*** \\ Agnes Scott Faculty, Georgia, EUA
}

\begin{abstract}
Given the cyclical nature of economic crises, this paper aims to demonstrate the importance of employment as a means of promoting the expansion of individual capabilities. It analyzes the Brazilian labor market and its characteristics, eliciting the relevance of addressing the quality of work, especially about its precarity, focusing in
\end{abstract}

\footnotetext{
* Gustavo Barby Pavani - PUCPR - Lawyer, Bachelor of Laws at UNICURITIBA, Especialist in Labor and Processual Labor Law at EMATRA/PR, Master's Student Program at the Pontifical Catholic University of the State of Paraná. E-mail: gustavobarbypavani@gmail.com.

** Marco Antônio César Villatore - PUCPR - Lawyer, Bachelor of Laws at Federal University of the State of Paraná. PHD at University Roma II, "Tor Vergata", Doctor at University of the Roma I, "La Sapienza"/UFSC and Master at Pontifical Catholic University of the State of São Paulo. Full Professor of Pontifical Catholic University of the State of Paraná; of UNINTER and of Federal University of the State of Santa Catarina. Email: marcovillatore@gmail.com.

*** Public Policy PHD in University of North Carolina - Multi-Campus University. Political Science Profesor at Agnes Scott Faculty (Georgia, EUA).

Este trabajo fue recibido el 10 de julio de 2018 y aprobado el 23 de agosto de 2018.
} 
reducing inequalities and social exclusion. The paper also outlines about public policies applied by the Brazilian government and points out some alternatives for the country's labor market based on the expansion of personal freedoms.

Keywords: economic crises; capability approach; Brazilian labor market; employment; public policies.

Resumen: Dado el carácter cíclico de las crisis económicas, este artículo pretende demostrar la importancia del empleo como medio para promover la expansión de las capacidades individuales. Analiza el mercado laboral brasileño y sus características, destacando la relevancia de abordar la calidad del trabajo, especialmente sobre su precariedad, centrándose en la reducción de desigualdades y de exclusión social. El trabajo también describe y cuestiona las políticas públicas aplicadas por el gobierno brasileño y señala algunas alternativas para el mercado laboral del país, basadas en la expansión de las libertades personales.

Palabras clave: crisis económicas; enfoque de las capacidades; mercado laboral brasileño; empleo; políticas públicas.

\section{Introduction}

It is of fundamental importance the understanding by the State and the business community about the development of economic activity. This knowledge is especially necessary because crises, which are inherent to the system, will reoccur, and economic agents - either regulators, as State, or those who drive the market machine, as entrepreneurs - must be ready to overcome the difficulties inherent in overproduction and financial speculation, mechanisms that inevitably lead to crises.

As part of the capitalist economic system in a world of increasingly accelerated processes and globalized markets, regardless of where economic crises take place, they will certainly affect all global economic actors.

Despite Brazilian protective labor legislation -established to protect workers- and State as not only guarantor of Labor Justice, but also the leading formulator and regulator of labor policies, preserving the dignity at work and balance in the employment relationship, that legislation falls far short of guaranteeing a major role for employment in economic conciliation. In the last capital crisis, the implementation of urgent measures to reduce taxes on economic activities was necessary intending to boost consumption, increase credit, and thus stimulate market growth to preserve employment.

Even though those politics have effectively prevented larger repercussions of the crisis, it resulted in collateral effects - growth of pejotização, reduction of formal (and legally protected) employment contracts and greater difficulty of labor market inclusion for young people with higher levels of education - for the reason that the country`s economic framework shifted to products with low added values.

The altered labor framework brings a progressive rise in internal prices of food and basic commodities for the population, caused by the change of internal production to the external market, analogous to a perverse pendulum - on one side, the reduction of formal employment contracts, and on the other, the rise in living costs and labor reproduction.

Because of the economic crisis, this dichotomy makes many people to lose their formal employment and simultaneously fail to reenter the market, which also affects their 
financial subsistence, given the rise of basic living costs and commodities. Therefore, the repercussion of world crisis must be investigated in its social and corporate context, including how Labor Law can aid employees and employers in overcoming those crises.

This article intends to demonstrate the intimate relation between economic crises and labor market changes, and consequently in Labor Law, with an important discussions and debates about the subject.

Although this economic crisis reflected the financial crisis, obviously its consequences have been felt worldwide, given that it transfers employment from areas where the Labor Law is more structured to those with reduced labor and production costs, as well as less commitment to social costs and income transfer.

Developing countries have a historical conflict between the scarcity of job opportunities and the limitation of their governments in providing social protection measures to the unemployed. This concern is more relevant during economic crisis, with higher unemployment rates and, consequently, an increase in the demand for social benefits provided by the governments.

Not only is unemployment itself an important indicator, but also a great number of other variables related to the labor market, such as the reduction of labor rights, more flexible regulations, informal working, entrepreneurship by necessity, self-employment, etc.

However, despite the importance of those other variables related to the labor market, most of analyses, including and especially those conducted by the government, fail to capture the big picture.

In his works, Amartya Sen maintains that the assessment of a state or action cannot be limited to a sole indicator or criterion of evaluation (Sen, 1987: 58-59). The informational basis must be wide so that the whole panorama can be encompassed by the analysis. Applying that perspective to the labor market evaluation, relying only on unemployment, despite its importance as an indicator, is incomplete.

Sen's argument is of great relevance to the examination of the Brazilian scenario since the labor market is most commonly made in terms of increasing or decreasing unemployment rates rather than using a wider informational basis. That includes not only the assessment of labor market by its quantity, but also by its quality (Sehnbruch, 2004), mainly related to the forms of labor and the reduction of labor rights.

The quality of the labor market has a direct effect on individual welfare. To begin with, formal employment brings a great number of benefits for the individual, not only income but also a variety of direct and indirect benefits, which are absent in other forms of labor, such as informal labor and self-employment.

Using the capability approach, the research aims to evaluate how formal employment can increase the set of capabilities a person has, and consequently how and why the employment can help a person achieve what he defined as value.

In that sense, it is important to highlight the government role in this area, as a tool to expand capabilities by removing the obstacles that prevent people from achieving freedoms.

Finally, the study will demonstrate how Brazilian government acts in a contrary way, by promoting precarious forms of work and reducing labor rights, including changes brought by recent labor reforms that negatively affect workers' sets of capacities, that help employees flourish and expand their freedoms. 


\section{Brazilian labor market}

The history of the Capitalism is permeated by economic crises. Only in the 20th and beginning of 21 st century is possible to list a series of episodes worldwide, being unfeasible to point every episode registered at a regional level. The conclusion is that economic crises are inseparable from the capitalist system.

Michal Kalecki arguments that the growth of national wealth itself contains the «seed» for a depression, given that the additional income generated is only potential. This situation materializes because a substantial share of capital remains idle and will only be useful on the next recovery (Kalecki, 1977: 27). That's what happened in the event in analysis.

In 2001, United States faced an economic crisis arising from the burst of tech companies bubble, also known as dotcom crisis. Synthetically, what happened was a strong speculation in late 90's and the rise of internet-based companies' shares on the stock market. This euphoria was due to the combination of two factors: high expectations related to the profitability of this innovative sector, combined with low interest rates practiced by the Federal Reserve. It was claimed a new economy was arising.

In 2009, when presenting the Brazilian report about economic crises and Labor Law in the «XIX Congresso Mundial de Direito do Trabalho e da Seguridade Social» (Villatore; Hasson, 2009), one of the question answered was the percentage of formal employment in our country. Estimative made by Brazilian government pointed that 50.8\% (46 million people) of workers paid the social security, and in 2007, 2.4 million people joined the formal labor market.

Back then, in 2010, Brazilian Labor and Employment Minister, Carlos Lupi, stated at the «'X Encontro Nacional de Estudos Estratégicos' (ENEE)» that during the crisis, in 2009, Brazil created 1.7 million formal work positions, meanwhile, US lost 6.5 million, and Europe lost 10.2 million. Also, he declared that Brazil had a growth of $64 \%$ in the wage above the inflation and a 36\% gain in admission wages (Ministério do Trabalho e emprego, n.d).

It is important to highline that Brazilian business activity is no different than most of the countries that went through social and economic difficulties after 2008, given that micro and small business are the rule in our society, but their share in income -mainly in trade and services- is minimal compared to medium and large companies.

After ignoring the intensity of the crisis, Brazilian government started to introduce a series of measures to minimize the internal impacts of it. Some of those measures will be pointed very superficially, but it is important not to forget that many collateral measures also had influence in the evolution of Brazilian crisis. However, that is a problem for another paper.

Initially, the government tried to minimize the shortage of credit in the international market by rising domestic credits, reducing mandatory deposits for the banks and interest rates, with the objective of boosting internal economy to compensate the reduction of exportation.

One of the boasted tools to face the crisis was the «Plano de Aceleração do Crescimento - PAC», which, however, was seen more as political marketing with views for 
the election than a serious and structured program of sustainable growing, reason why the results were and still are mediocre.

Unemployment has been a major issue in Brazil and in most developing countries, especially in Latin America. For several reasons, including the fast-growing labor market and transition from rural to urban areas, the labor market in those developing countries did not absorb the labor force (Sehnbruch, 2004).

The last two decades in Brazil showed two very distinct situations concerning labor market and unemployment rates. Those situations go from full employment to a high unemployment level in a very short period. Full employment, for this study, relates to the definition of the availability of decent labor for every person who seek it (International Labor Organization, n.d).

On the early 2000's unemployment rates reached levels as high as $13 \%$, a number that gradually reduced in the following years. The full employment status was closely achieved in the years of 2012 and 2014 when the rates reached between 4 and 5\%. (Instituto de Pesquisa Econômica Aplicada. IPEA, 2016) That growth was especially influenced by public policies and expenditures that stimulated and financed investments of the private sector.

However, the government program that helped generate this employment growth also had an unsustainable basis of high public expenditure, especially due to the direct influence of the State in the economy, subsidies, tax breaks and incentives. Eventually, that model showed economic signs of exhaustion. Allied to a heavy political crisis, the impact on Brazilian economy was extremely strong, reaching a recession and influencing negatively the labor market - unemployment rates in the first trimester of 2017 reached 13,7\% (Instituto de Pesquisa Econômica Aplicada. IPEA, 2017).

Despite the relevance of the general numbers presented and its linkage with economic development, even when the unemployment rates were close to full employment there is an important indicator hidden that relates directly to the quality of the labor marketthe formal employment.

The formal employment, from here named just employment (species), refers to the formal and legally binding relationship or contract between a worker -who have (sometimes only) his labor force as the alternative of subsistence- and his employer, that compensates the work provided with a wage and other benefits. In this case, are excluded from the concept of employment other forms of work (gender), like informality, represented by the lack of social protection and labor rights provided by an employment contract.

In Brazilian analysis of labor market, the number used to exhibit unemployment considers the percentage of people within the economically active population that are seeking a work position. All other people within the economically active population are considered as workers. However, an important indicator that is often not considered and should be analyzed is the kind of employed position that the majority of the economically active population is allocated.

The numbers show that in the first trimester of 2015, 10.9\% of all the gainfully occupied population in Brazil was occupied in the informality, while $39.2 \%$ of all employees had an employment contract. Also, 23.7\% of the gainfully occupied population were self-employed and 4,4\% were employers. (Instituto Brasileiro de Geografia e Estatísticas - IBGE, n.d). In that trimester, unemployment rates were at $7.9 \%$ (Instituto de Pesquisa Econômica Aplicada, 2017). 
It is important to discern the variables in unemployment rates presented before. Despite the drastic increase in unemployment between the first trimester of 2015 and 2017, there is also a decrease in the percentage of employment contracts and an increase of informality and self-employment. In 2017, 37.6\% of occupied workers were under an employment contract, while $11.4 \%$ were working in the informal private sector. A similar increase was noticed on self-employment, with $24.9 \%$ rates, and employers, with $4.6 \%$ (Instituto Brasileiro de Geografia e Estatísticas - IBGE, n.d).

It is necessary to consider the numbers related to self-employment and entrepreneurship by necessity: an entrepreneur is an individual that acts moved by personal fulfillment, autonomy, connected to the idea of innovation and grasping business opportunities (Santos, 2003: 249-262). That concept of entrepreneur relates to the figure of the «entrepreneur by opportunity».

Given the economic challenges and unemployment, another category of entrepreneur arises. The «entrepreneur by necessity» is the person that, facing unemployment and difficulties of getting a reallocation in the labor market, choose to be entrepreneurial once is the only possible alternative for their incomes (Vale; Correa; Reis, 2014: 311-327). Brazilian government considers «entrepreneur by necessity» those who start a commercial activity moved by the lack of work opportunities and have to start a business in order to generate income for themselves and their families (Portal Brasil, n.d; Instituto Brasileiro de Geografia e Estatísticas, n.d).

It is also named self-employment, in which the worker finds himself in a simultaneous position of employee and employer, taking over the risks of the activity and leaving aside the assurance of a monthly wage. However, opposed to the entrepreneur by opportunity, the main goal is not capital accumulation, but to provide means of subsistence (Pamplona, 2001: 78).

Researches show that in 2016, entrepreneurship by necessity rates were around $42 \%$ against 57\% entrepreneurship by opportunity. For comparisons, 2013 rates were the lowest, with rates at $29 \%$ for entrepreneurship by necessity. (Global Entrepreneurship Monitor, 2017:31).

In recent years, despite the poor performance of GDP between 2014 and 2017, the annual creation of new «MEI» ${ }^{1}$ has remained robust, close to 1 million new «MEI» per year. Because of this, the creation of new «MEI» seems to be more associated with the process of formalization of the business than with the pace of growth of the economy. Note that the following factors has favored this process: the low cost for creation / maintenance of the MEI; the reduced bureaucracy involved in the registration of the «MEI»; the high stock of individuals who still owns a business in informality. Thus, it is reasonable to assume that in 2018 there will be a continuation creation of «MEI», at a level close to 1 million «MEI» per year (SEBRAE, 2018).

Still, in 2017 the Global Entrepreneurship Monitor mapped the motivations for the entrepreneurs. It is estimated that $16,313,323$ million entrepreneurs were motivated by opportunity, and 10,965,755 million, by necessity (Global Entrepreneurship Monitor, 2017).

In addition, the protection of regular employment and its effectiveness as a possibility for workers occurs at the Constitutional level, but also is pursuant to art. 1 of the

\footnotetext{
${ }^{1}$ Individual micro entrepreneur.
} 
Convention signed in Paris on December 14, 1960, promoted by the Organization for Economic Co-operation and Development (OECD). This institution sought, as one of the foundations to raise employment rates, fulfilling the ideals provided for in the Constitution of the International Labor Organization.

Despite this protective construction, the reality in Brazil's internal environment denotes the distance of these ideals. As examples, we can cite the successive reforms that came before Law 13.467/2017, such as the outsourcing itself (Antunes, Druck, 2013) and minimally regulated rights, such as domestic employees regulated only with Constitutional Amendment No. 72/2013 (Figueiredo, Hazan, 2014: 265-278), and now with Law no. 13.467/2017. The speeches of flexibilization and deregulation are always present. Nevertheless, when these discourses are materialized in laws, they generate unemployment and economic crises (Zockun, 2010: 208-209), and these facts contribute to entrepreneurship out of necessity.

Therefore, unemployment is not only increasing, but also the quality of employment is constantly decreasing, with the reduction of employment and rising of informal work and self-employment. Those precarious forms of labor affect not only the individual but also the Brazilian society, as will be further demonstrated.

\section{Employment, capability approach and reduction of inequalities}

Regarding the evaluation of labor market, mainly related to economic aspects, most of the analysis is made using as an indicator just the (un)employment rates or average income received by workers. Despite its importance as an indicator, problems demand an analysis on a wider informational basis.

Throughout his works, Sen develops his studies analyzing, and then criticizing, the usage of only one informational basis to the assessment of a determined state, mainly because of the limitations produced by a sole indicator (Sen, 1987: 58-59). Likewise, using just one achievement as a criterion of analysis is wrong, given that it does not capture the individual characteristics in an interpersonal comparison (Sen, 1992:26).

Sen criticizes the criterion of income, commonly used in economics, to demonstrate the mistake of just one criterion of evaluation. For example, the difference between a normal person and a disabled person, with the same level of real income and opulence, but that cannot do many things a normal person can (Sen, 1985: 196).

Sen uses and develops the capability approach, which «sees human life as a set of doings and beings». Those doings and beings are called functionings. Capabilities are the present and potential functionings that a person can have if he or she desires. Those capabilities may vary from basic and essential ones, related to the mere living, like being well nourished, have good health and housing, to more complex and personal examples, such as achieving self-respect or being a part of the community (Sen, 2003: 43).

It is important to emphasize that the valorization of work is a prerogative of the human person, and through this association, the doctrine of Human Rights (Cançado Trindade, 2004: 212) was consolidated. This doctrine deals with rights that are superior to the human being itself and it has a global range, which means it is added to the nationalities and the political statutes (Buergenthal, 1998: 7)

Flávia Piovesan emphasizes that the International Labor Organization, working with the League of Nations and Humanitarian Law, has contributed to the construction and 
internationalization of the human rights. These institutions proposed the valorization of rights as real commitments, altering the idea that the international law should regulate only the relations between states (Piovesan, 2013: 185-187). Thus, the primacy of work, which is the ILO's essential foundation, is one of the milestones of the consolidation of this and other rights that permeate human reality.

According to Antônio Enrique Perez Luño, the Human Rights, which are effectively materialized by labor law, are a «set of faculties and institutions» that concretize a system dedicated to materialize the «requirements of human dignity, freedom and equality» (Luño, 1995: 48). Work that are protected by law encourages these kind of ideals.

The strengthening of human rights ruptures the notion of absolute sovereignty, which means that it is no longer permissible for states to consider the rights of individuals as «matters of their exclusive interest» (Henkin 1993: 7-9) (Cançado Trindade, 1991: 5).

Valued capabilities enable people to achieve rights effectively. A person's set of capabilities reflects the freedom that he or she has to obtain a particular functioning arrangement. The alternatives that a person has are important to judge his or her advantage (Sen, 2003:48).

In the distinction of functionings and capabilities, the most important element is the freedom that a person has to choose the kind of life that he or she desires. That is one of the main differences between the capability approach and the one based accomplishments (Sen, 2003: 55).

Through this perspective, work can provide access to basic capabilities such as the use of wage to obtain food and housing, and also more complex ones, like personal growth or social participation (Sehnbruch, 2004).

Applying the capability approach to the labor market would result in enhancing people's freedom to choose a job or activity that they have a reason to value (Bonvin, 2012: 9-19).

In one of his books, when discussing poverty and famines, Sen indicates that rich countries don't have famines not because of their richness, but because of the minimum entitlements provided by their social security systems (Sen, 1981: 7).

Developed countries, like Germany and Spain, have active policies to help people achieve employment, and consequently, to add the option «being employed» to their capability set. Those policies may vary from capacitation, education, or even through direct financial assistance, received by the individual while searching for a job opportunity that he or she desires. (Bartelheimer; Verd; Lehweß-Litzmann; López Andreu; Schmidt, 2012: 3144)

Sen has already advocated for the universality of coverage and attention to decent jobs for all kinds of workers -unregulated workers, self-employed, homeworkers- not only to those who already are employed. Nevertheless, it is a vision aimed to reduce social exclusion of those who are not protected (Sen, 2000).

The strict use of that proposition may be primarily theoretical and, in some sense, practically unrealistic for developing countries, given that it depends primarily on social protection measures and social security systems that are, in general, lacking in those countries.

Even if that was not the case, and if all countries had a strong social protection system for the unemployed, the subject is far more complex than just income support. 
Unemployment affects negatively both social and personal life in different ways, and its consequences that go beyond low income. In a social aspect, unemployment influences the economy, with low expenditures from individuals and families. Also, it puts a direct burden on the State to support the unemployed people, and an indirect one to the contributors that pay more taxes to fund that system (Sen, 1997: 155-172).

However, the personal effects are the most vicious ones, that go far beyond income lowness. Sen lists several losses in unemployment, such as loss of freedom and social exclusion, skill loss, psychological and health harms, loss of motivation, loss of personal relationships e social values, and the increase of racial and gender inequalities (Sen, 1997: 155-172).

On a wider analysis, unemployment affects not only the person without a job, but can also affect his or her family, in the case of children dependent on a father or a mother in a home. It can harm the children's access to education and make them join the labor market sooner than expected, impeding them from getting a higher education (Sehnbruch, 2004).

The importance and relevance of the employment and its social role are clear, given that it is where inequality expresses itself. Sen argues for a combination of successful structures, on one hand, that is, the social protection provided by developed countries in Europe, and on the other hand, the American position on employment policies (Sen, 1997: 155-172).

It follows that employment is one of the most important forms to expande freedoms and to reduce inequalities in developing countries. As an alternative, the application of the capability approach should focus also in identifying the obstacles that prevent the expansion of a person's freedoms regarding the labor market; in this case, those related to the quality of labor market, such as informality, self-employment, etc.

That evaluation with a larger number of variables has a direct effect on the public policies related to the labor market. Using just unemployment numbers would not show the characteristics of the occupied working positions. A wider informational basis is essential for a better analysis of working population and its quality.

Employment is an important mechanism of social regulation, given that it assures minimum warranties for the worker. To demonstrate the importance of employment, Brazilian legislation can be used as an example, given that most of the social protection system is only available for those who are employed, such as compensation for unjustified dismissal, social security related to temporary inability, and even basic labor rights like maximum daily journey, vacation time, union rights, etc.

One of the few social policies that give some protection to a person recent unemployed is conditioned to a previous employment, that is, the person that has recently been fired will have access to a temporary income provided by the government.

Those few examples of labor and social rights that are not available for other workers shows that not only unemployment is a space for the manifestation of inequality, but also precarious forms of labor contribute for those inequalities to manifest.

\section{Brazilian public policies regarding labor market}

As presented earlier in this paper, public policies should include into its analysis not only the reallocation of unemployed persons into the labor market but also present 
alternatives to fight informality, self-employment, amongst other forms of precarious work that reduce people's capabilities.

Given the characteristics of neoliberal economies, the social function provided by the government was gradually shared with the business sector, mainly through employment and its social function; Brazilian Constitution establishes in its article 5 XXIII, the social function of property. The entrepreneurial freedom is no longer legitimate if practiced only targeting profit, but must act accordingly to the limitations established by the government, in the interest of social justice (Silva, 2005: 794).

This is of great importance, not only for individual advantages of employment, but also for the government and the society. It is a powerful mechanism for tax collection, control, and regulation, especially in Brazil. In a broader analysis, employment is a way for the government to shrink its exclusive responsibility, like providing health and even education.

Therefore, it is undeniable that employment acts in benefit of the society, directly or indirectly, as it strengthens democracy, acts as a social regulator, finance the government, sustains social security and provides a minimum of warranties and safeties for the workers.

Despite that, it appears that the opposite path is taking place, as business start sharing the risks of their activities with the workers. Even though it is comprehensible despite objectionable- that companies try to reduce costs in any area possible, including labor costs. However, the real problem occurs when that movement goes beyond the private sector, into the government and legislators that act to reduce labor rights and legalize and incentive precarious forms of labor.

Recent modifications in Brazilian labor legislation have shown the power that some companies have to influence the government, also called «rentseeking» (Zingales, 2015: 37 ), that cause a drastic reduction of labor rights. In that case, companies do not try to be competitive through innovation or adaptation, but to influence legislators to act on their interests.

On the other hand, there are those unemployed workers that have the selfemployment as the only alternative, as well the workers in informality that do not have any social protection, social security or minimum rights and safeties provided by an employment contract.

Certainly, employment should be the main goal of public policies, given the already mentioned advantages brought by it. In addition, as argued by Sen, it is extremely important not to leave other workers unprotected, and government attention should also be directed for those workers, targeting decent working conditions and minimum rights and social protection (Sen, 2000). Therefore, is in that vacuum of social protection that governmental action should take place, valuing employment and reducing precarious forms of work.

The ideals of flexibilization and deregulation emerge as a strong critique of state interference and the «excess of labor laws», that would be against the logic of the labor market. (Ramos Filho, 2012: 49) On the other hand, in the twenty-first century, deregulation would be carried out by a state action in favor of the business class (Ramos Filho, 2012: 49).

Thus, the proposals for a labor reform consolidate a «market of legislative products». That is, the labor legal system is used for the wills, ideals and needs of the 
financial market (Amado, 2009: 100-187). Alain Supiot points out that this phenomenon is a «normative Darwinism».

According to the author, labor law is perceived as a product of competition, and thus, there will be a dispute and the chosen regulations will be the ones that suit the wills of the economic order, which favor the economy (Supiot, 2005: 122-136). Adaptations that are imposed on historically constructed labor systems enforce the «economic instrumentality of labor law» (Fernandes, 2014: 23).

However, especially during the last decade, Brazilian scenario shows public policies targeting the incentive of autonomous work, entrepreneurship of individual business (most commonly related to self-employment), and other forms of works without the social protection provided by employment. As an example, the recent Complementary Law $128 / 2008$, that creates the figure of the individual micro entrepreneur, aimed to the formalization of self-employed people.

\section{Alternatives based on the capability approach}

Those changes in Brazilian legislation comes with a false idea of creation of jobs, economic growth, and reduction of social inequalities that do not sustain itself when empirically analyzed. One important motive for that is related to the absence of a distinction between entrepreneurship by necessity and opportunity in public policies and incentives.

Comparative studies show that in less developed countries, even with high rates of entrepreneurship, there is no proven relation between the entrepreneurial activity and social or economic development (Barros; Pereira, 2004: 50-64). Those positive achievements are only verified with the increase of entrepreneurship by opportunity (Oliveira; Cardoso, 2015).

The result can be quite the opposite, especially in Brazil, where entrepreneurship by necessity has high rates. Reasons for that negative relation are, for example, the elevated number of insolvency of those businesses, lack of information on the market and experience in the chosen area. The survival rates of small companies are extremely worrying, as numbers show that in 2014, five years after joining the market, almost $70 \%$ of the companies with no employees and $40 \%$ of the companies with 1 to 9 employees, were closed. Therefore, it is possible to observe that survival rates have a direct relation to the size of the business: small business without employees, where are most commonly located individual micro-entrepreneurs, have the lowest survival rates. (Instituto Brasileiro de Geografia e Estatísticas, 2016)

While Brazil has serious employability issues, especially in the last three years, seems illusory that full employment could be achieved in a short time - however, it should always be treated as a goal.

Not only the economic problems faced by Brazil are an obstacle, but also the government position, that runs in an opposite direction considering the one that social assistance does, including public policies that incentive working positions without social protection. Even in the employment area, the government actions are directed to the reduction of labor rights, alleging that more flexible rights would generate more employment. 
Economy is recovering gradually, and unemployment is reducing, despite the already mentioned low quality of working positions. At this point, it is important to reformulate public policies and adopt ones that embrace economic recovery and focus on the quality of working positions, as well as decent works.

As already advocated, given its advantages, employment should always be the first goal. However, the exclusion of other workers is even more harmful. Public policies should target the universality of coverage, with a broad focus on all the working positions, for a more «comprehensive approach» (Sen, 2000).

Some ideas of public policies that give a minimum of protection to other forms of work can be found in European countries. Countries like Italy, Spain, and Germany have legislation that grants certain rights for those entrepreneurs and autonomous workers that are disadvantaged (Goulart, 2012: 77-78).

If in certain situations entrepreneurship by necessity is inevitable, public policies should aim not only giving people some rights or income assistance but also enhancing people's capabilities and helping the activity to become sustainable at medium and longterm. In that sense, an alternative is the creation of public policies orientated to training programs, capacitation, and education of entrepreneurs (Vale; Correa; Reis, 2014: 311$327)$.

Likewise, in the unemployment area, the policies should aim a more individualized assistance, not only in terms of income but also by increasing individual capabilities that are valued by each person seeking for an employment. That would help them to achieve options that were inaccessible for those workers and could become a form to reduce inequalities (Bartelheimer; Verd; Lehweß-Litzmann; López; Schmidt, 2012: 31-44).

Therefore, public policies should aim the expansion of individual capabilities, through a multifocal analysis of labor market in all its forms -focusing the employment because of all its advantages- but also reducing inequalities and exclusion through policies that include other workers and unemployed people seeking for a job position.

\section{Conclusion}

Unemployment is a reality worldwide, in developed, developing, and underdeveloped countries. Even as a cyclical issue related to the global economy, this problem directly affects the lives of individuals and societies across the planet. Despite its importance as an indicator, labor market issues go deeper than just unemployment, especially when it comes to questions of the quality of working occupations.

The Brazilian scenario shows that even with a slow recovery of unemployment rates, formality is diminishing and being replaced by precarious forms of labor, such as informal work and self-employment. Those types of occupations lack social protection and leave those workers excluded from rights granted to employed individuals.

From all that has been discussed, it is important to have in mind that the answer to maintaining jobs during crises starts with the goodwill of States in reducing social charges, but not only with this one policy. In addition, the state should provide for those who lose their jobs by increasing unemployment insurance because companies will have greater difficulties in hiring new employers for a longer term.

It is essential to ask what forms and activities of business are possible and compatible with its own responsibilities, even in times of economic crisis, to guarantee a 
sustainable development, by preserving employment, entrepreneurship, and sustainability itself.

It is responsibility of all members of the society to refuse to a precarization of labor and rights, given that, for good or ill, Brazil was able to reach the historical mark of more than $50 \%$ employment formalization.

Flexibilization is an elegant way of cheering on the abandonment of employee protection. Will we be forced to understand the precariousness of rights as an imperative necessity of the society in the $21^{\text {st }}$ century? Is it possible that the Welfare State as a model has been lost as an alternative model for capitalism?

Those are questions that lead us to a compelling form of choice and the partisanship of our comprehension of the working world: on one hand, it attempts to accelerate the ruthless deconstruction of rights of workers. On the other hand, it focuses on transformations of society and the pursuit of constructing a new Labor Law, one that is more protective, more judicial, less atavistic, and more responsible. Beyond treating the employee as the weaker party and the employer as culpable, it must comprehend that there is a conflict of interest between the parties and that the State must be strong enough to impose rules considered just by society and in society's benefit, necessitating a herculean effort to rewrite all the Labor Law.

Economic crises will come and go, and with them, new institutions that produce precarious employment. However, there is no factor so effective in lessening harmful effects of crises on society than State actions to reduce taxes for micro and small businesses, who create most employment in Brazil.

Public policies must change their focus, since nowadays they enhance incentives to increase precarious forms of labor, especially by promoting entrepreneurship activities and reducing labor rights conquered with difficulty by employees during the last years.

In that sense, Amartya Sen's capability approach can be used as an alternative for assessing those public policies targeted to increasing people's capacities. For that, the analysis must comprehend a broader picture, not focusing only on unemployment rates, but also on the quality of jobs, individual capabilities, and reduced inequalities.

Entrepreneurship by necessity is a clear form of work that leads in the opposite direction from expanding freedoms, given that a person does not choose to start a business, but rather is forced to do so as the only means of subsistence. Even if that was not the case, empirical studies show that this form of entrepreneurship does not generate economic and social development.

A critical analysis must be made, exposing the risks of a false entrepreneurial society, starkly unprotected, especially because the government is directly supporting that model through legislation and public policies based on a false and unproven idea of social and economic development.

Public policies should aim, in the first place, at incentives and valorization of employment and guarantees of worker rights, as means of social control and regulation, strengthening democracy, and helping to support the State and social security finances. At the same time, policies must search for ways to give a minimum social protection to workers who do not have a formal employment, especially those self-employed workers, and to guarantee some security and social justice.

As the achievement of full employment is utopian in short term, a multifocal analysis and action is demanded. Alternatives can be seen in European countries that 
provide some rights and assistance for those who are unemployed or self-employed. Not only income support, but also capacitation, training, education and other forms of capability expansion are called for.

Countries should adopt those possibilities so that people can have the opportunity the capabilities- to search and pursue the roles they actually desire, and in the process, reduce inequalities and social exclusion.

\section{References}

Amado, João Leal (2009). «Dinâmica das relações de trabalho nas situações de crise». Revista do Ministério Público, 30 (120): 187-100.

Antunes, Ricardo e Graça Druck (2010). «A terceirização como Regra». Revista TST. 79 (4).

Barros, A. A. \& C. M. A. Pereira (2008). «Empreendedorismo e crescimento econômico: uma análise empírica». RAC. Revista de Administração Contemporânea, Vol. 12: 5064.

Bartelheimer, P.; J. M. Verd; R. Lehweß-Litzmann; M. López Andreu e T. Schmidt (2012). «Unemployment, intervention and capabilities. A comparative study of Germany and Spain». European Review Of Labour And Research, 18 (1): 31-44.

Bonvin, J. M. (2012). «Individual working lives and collective action. An introduction to capability for work and capability for voice». European Review of Labour Research, $13(1): 9-19$.

Buergenthal, Thomas (1998). International human rights in a nutshell. USA: West Publishing Co.

Cançado Trindade, Antônio Augusto (1991). A proteção internacional dos direitos humanos: fundamentos jurídicos e instrumentos básicos. São Paulo: Saraiva.

Cançado Trindade, Antônio Augusto (2004). «Direitos Humanos: Personalidade e capacidade jurídica internacional do indivíduo». In: Brandt, Leonardo Nemer Caldeira (org.). O Brasil e os novos desafios do Direito Internacional. Rio de Janeiro: Forense.

Fernandes, Antônio Monteiro (2014). Direito do Trabalho, 17 ed. Coimbra: Coimbra Editora. Barros, A. A. \& C. M. A. Pereira (2008). «Empreendedorismo e crescimento econômico: uma análise empírica». RAC. Revista de Administração Contemporânea, v. 12: $50-64$.

Figueiredo, Bruno Reis de e Ellen Mara Ferraz Hazan (Org.) (2014). Alguns aspectos sobre a terceirização. Belo Horizonte: RTM, p. 265-278.

Goulart, R. F. (2012). Trabalhador autônomo e contrato de emprego. Curitiba: Juruá.

Henkin, Louis (1993). The internationalization of human rights. 3 ed. Minnesota: West Publishing.

Kalecki, M. (1977). «O Mecanismo da Recuperação Econômica». In: Miglioli, J. (org.). Crescimento e Ciclo das Economias Capitalistas. São Paulo: Hucitec.

Kindleberger, C. P. \& R. Z. Aliber (2009). Da euforia ao pânico: uma história das crises financeiras. São Paulo: Editora Gente.

Luño, Antonio Enrique Perez (1995). Derechos Humanos, Estados de derecho y Constitución. 5. ed. Madrid: Tecnos.

Oliveira, I. G. S. \& S. P. Cardoso (2001). «Empreendedorismo e suas implicações na inovação e desenvolvimento: uma análise multivariada de dados com indicadores 
socioeconômicos». In: Pamplona, J. B. Erguendo-se pelos próprios cabelos: autoemprego e reestruturação produtiva no Brasil. São Paulo: Germinal/FAPESP, p. 78.

Piovesan, Flávia (2013). Direitos Humanos e o Direito Constitucional Internacional. 14. ed. ver. e atual. São Paulo: Saraiva.

Ramos Filho, Wilson (2012). Direito Capitalista do Trabalho: História, Mitos e Perspectivas no Brasil. São Paulo: LTr.

Santos, F. C. G. dos (2003). «Empreendedorismo utópico: políticas públicas de fomento ao empreendedorismo como uma alternativa para o desenvolvimento econômico local». In: EGEPE - Encontro de estudos sobre empreendedorismo e gestão de pequenas empresas. Brasília. Anais. Brasília: UEM/UEL/UnB, p. 249-262.

Sehnbruch, K. (2004). From the Quantity to the Quality of Employment: An Application of the Capability Approach to the Chilean Labour Market. Centre for Latin American Studies, Berkeley, CLAS Working. Paper N. 9.

Sen, A. (2003). «Development as capability expansion». In: Fukuda-Parr, S. et al (eds.) Readings in human development. New Delhi; New York: Oxford University Press.

Sen, A. (1992). Inequality Reexamined. Oxford: Oxford University Press.

Sen, A. (1997). «Inequality, unemployment and contemporary Europe». International Labour Review, 136 (2) 155-172.

Sen, A. (1987). On etichs and economics. Oxford: Blackwell.

Sen, A. (1981. Poverty and Famines: An Essay on Entitlement and Deprivation. Oxford: Clarendon Press.

Sen, A. (1985). «Well-being, agency and freedom: The Dewey Lectures 1984». The Journal of Philosophy, 82, (4) 169-221.

Sen, A. (2000). «Work and rights». International Labour Organization 2000 International Labour Review, 139, (2).

Supiot, Alain. (2005). «O direito do trabalho ao desbarato no "mercado das normas"». Questões Laborais, XII, (26).

Vale, G. M. V.; V. S. Correa e R. F. Reis (2014). «Motivações para o empreendedorismo: necessidade versus oportunidade?». RAC. Revista de Administração Contemporânea (On line), 8, 311-327.

Villatore, M. A. C. \& R. Hasson (2009). Relatório brasileiro do XIX Congreso Mundial de Derecho del Trabajo y de la Seguridad Social. Sydney, Austrália, 1-4 de setembro de 2009, in: «http://www.upf.edu/gredtiss/_pdf/islssl-spanish.pdf»

Zingales, L. (2015). Um capitalismo para o povo. São Paulo: BEI.

Zockun, Carolina Zacaner (2010). «A Intervenção do Estado na Ordem Social e o Direito ao Trabalho». In: Sparapani, Priscila e Renata Porto Adri (Coord.). Intervenção do Estado no domínio econômico e no domínio social: homenagem ao Professor Celso Antônio Bandeira de Mello. Belo Horizonte: Fórum.

\section{Documents}

Global Entrepreneurship Monitor. Empreendedorismo no Brasil: 2017. Simara Maria de Souza Silveira Greco; diversos autores.(2018). IBPQ.

Global Entrepreneurship Monitor. Empreendedorismo no Brasil:2016. Coordenação de Simara Maria de Souza Silveira Greco; diversos autores. (2017) Curitiba: IBQP. 
Instituto Brasileiro de Geografia e Estatísticas - IBGE. Demografia das empresas: 2014/IBGE. Coordenação de Metodologia das Estatísticas de Empresas, Cadastros e Classificações. - Rio de Janeiro: IBGE, (2016). Available at: «http://biblioteca.ibge.gov.br/visualizacao/livros/liv98073.pdf».

Instituto Brasileiro de Geografia e Estatísticas - IBGE. Sistema IBGE de Recuperação Automática - SIDRA. Available at: «https://sidra.ibge.gov.br/Tabela/4097».

Instituto de Pesquisa Econômica Aplicada. Carta de Conjuntura $n^{o}$ 36. IPEA, nov. 2017. Available at: «goo.gl/aLq55y».

Instituto de Pesquisa Econômica Aplicada. IPEA, fev. 2016. Available at: «http://www.ipeadata.gov.br/exibeserie.aspx?serid=38401».

International Labor Organization. Available at: «goo.gl/gfq4rw».

Ministério do Trabalho e Emprego. Notícia: Lupi fala sobre os desafios do Brasil para os próximos anos. In: «goo.g1/4LZ52H».

VI Congresso UFSC de Controladoria e Finanças. (2015) Florianópolis. Anais. 2015. Available at: «goo.gl/RV2oEZ».

Portal Brasil. Available at: «goo.gl/P8rVGJ». Instituto Brasileiro de Geografia e Estatísticas - IBGE. Sistema IBGE de Recuperação Automática - SIDRA. Available at: «goo.gl/uY5eTZ».

SEBRAE, Serviço de apoio às Micro e Pequenas Empresas. Relatório especial: os negócios promissores em 2018. Available at: «goo.gl/EXSMZm».

Serviço Brasileiro de Apoio às Micro e Pequenas Empresas - Sebrae. Unidade de Gestão Estratégica - UGE. Participação das Micro e Pequenas Empresas na Economia Brasileira. Julho/2014. Brasília/DF, in «goo.g1/2BMT1b». 